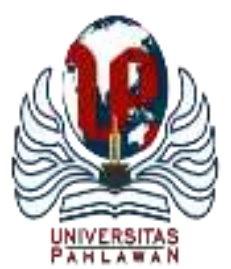

Edukatif : Jurnal Ilmu Pendidikan Volume 3 Nomor 6 Tahun 2021 Halm 3839 - 3851

EDUKATIF: JURNAL ILMU PENDIDIKAN

Research \& Learning in Education

https://edukatif.org/index.php/edukatif/index

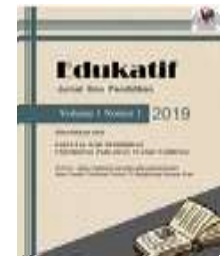

\title{
Tantangan Digitalisasi Pendidikan bagi Orang Tua dan Anak di Tengah Pandemi Covid-19 di Desa Bendanpete
}

\author{
Rizky Wulandari ${ }^{1 凶}$, Santoso $^{2}$, Sekar Dwi Ardianti ${ }^{3}$ \\ Universitas Muria Kudus, Indonesia ${ }^{1,2,3}$ \\ E-mail : $\underline{\text { rizbel199@gmail.com }}{ }^{1}, \underline{\text { santoso.pgsd@umk.ac.id }}{ }^{2}, \underline{\text { sekar.dwi.ardianti@umk.ac.id }}^{3}$
}

\begin{abstract}
Abstrak
Penelitian ini bertujuan untuk mendeskripsikan bentuk, tantangan serta dampak digitalisasi pendidikan di tengah pandemi Covid-19 di Desa Bendanpete. Penelitian menggunakan metode penelitian kualitatif fenomenologi. Subjek penelitian terdiri dari orang tua yang memiliki anak usia 6-12 tahun dan anak usia 6-12 di Desa Bendanpete. Teknik pengumpulan data yang digunakan berupa observasi, wawancara, serta dokumentasi. Hasil penelitian didapati bentuk dari digitalisasi pendidikan ditengah pandemi Covid-19 secara asynchronous learning (pembelajaran tidak sinkron). Adapun tantangan digitalisasi pendidikan bagi orang tua adalah ketersediaan paket data, manajemen waktu serta perubahan pola belajar. Tantangan digitalisasi pendidikan bagi anak adalah anak gagap teknologi. Sedangkan dampak positif digitalisasi pendidikan di tengah pandemi Covid-19 bagi orang tua adalah orang tua dapat memantau aktivitas belajar anak di rumah. Dampak negatifnya adalah orang tua kesulitan memahami materi anak dan pengeluaran membengkak akibat pemenuhan fasilitas pembelajaran daring anak. Sedangkan dampak positif digitalisasi pendidikan bagi anak adalah tersedianya media massa untuk mencari informasi serta waktu belajar menjadi fleksibel. Dampak negatif dari digitalisasi pendidikan bagi anak adalah anak tidak paham materi pelajaran, munculnya sikap malas belajar, penyalahgunaan teknologi selama pembelajaran daring, serta munculnya sikap acuh anak.
\end{abstract}

Kata Kunci: Digitalisasi Pendidikan, Orang tua, Anak, Daring, Covid-19 .

\begin{abstract}
The purpose of this study is to describe the form, challenges and the impact of digitizing education during pandemic Covid-19 in Bendanpete village. The research used descriptive qualitative with phenomenological research type. The research subjects are parents and also their children aged 6-12 years. Data collection techniques used in the form of observation, interviews, and documentation. The results of the study found that the form of digitalization of education was asynchronous learning. The challenges for parents are the availability of data packages, time management and the changes in learning patterns. Meanwhile, the challenge for children is that they are technologically stuttering. While the positive impact for parents is that parents can monitor their children's learning activities at home. The negative impact is that parents have difficult to understand their children's material and expenses increase due to the fulfillment of children online learning facilities. While the positive impact for children is the availability of mass media to find information and flexible learning time. The negative impact is that children do not understand the subject matter, the emergence of a lazy attitude to learning, misuse of technology during online learning, and the emergence of a child's indifferent attitude.
\end{abstract}

Keywords: Digitizing of Education, Parent, Children, Online, Covid-19.

Copyright (c) 2021 Rizky Wulandari, Santoso, Sekar Dwi Ardianti

$\triangle$ Corresponding author

Email : rizbell99@gmail.com

DOI : https://doi.org/10.31004/edukatif.v3i6.1312

ISSN 2656-8063 (Media Cetak)

ISSN 2656-8071 (Media Online) 
3840 Tantangan Digitalisasi Pendidikan bagi Orang Tua dan Anak Di Tengah Pandemi Covid-19 di Desa Bendanpete - Rizky Wulandari, Santoso, Sekar Dwi Ardianti

DOI : https://doi.org/10.31004/edukatif.v3i6.1312

\section{PENDAHULUAN}

Badan kesehatan dunia WHO pada awal tahun 2020 menerima laporan dari negara China tentang penemuan jenis virus baru yang diduga revolusi dari virus MERS yang juga pernah melanda di China ini dikenal sebagai Novel Corona virus 2019 atau lebih dikenal sebagai nCoV-2019. Virus Corona adalah virus yang menyerang saluran pernapasan yang pertama kali teridentifikasi di Wuhan, Hubei, China (Pennington, 2020). Penyebaran Covid-19 diketahui menyebar lewat cairan atau droplet dari orang yang terinfeksi dan akan menginfeksi orang yang belum terpapar. Penyebaran virus yang tergolong masif ini dikarenakan gejala awal yang dirasakan oleh orang yang terpapar virus ini yakni sama persis dengan gejala batuk pada umumnya (Mona, 2020).

Demi mencegah penyebaran virus yang semakin merebak, pemerintah Indonesia merujuk anjuran dari WHO menetapkan kebijakan baru atas situasi darurat yang sedang melanda negeri dengan cara menghentikan segala kegiatan yang memicu kerumunan dan berinteraksi dengan orang banyak atau sering kita dengar sebagai social distancing. Mengurangi intensitas interaksi antar manusia ini diharapkan pemerintah dapat memutus rantai penyebaran virus ke seluruh penjuru negeri dengan cara berdiam diri di rumah dan semaksimal mungkin menghindari kontak dengan orang banyak (Herdiana, 2020).

Kebijakan ini membuat segala roda kehidupan menjadi lumpuh, tidak terkecuali pada sektor pendidikan. Hakim (2016) menyebutkan penyelenggaraan pendidikan diselenggarakan sebagai suatu proses pembudayaan dan pemberdayaan peserta didik yang berlangsung sepanjang hayat. Prinsip tersebut sesuai dengan Undang-Undang No. 20 Tahun 2003 disebutkan bahwa pendidikan adalah usaha sadar dan terencana untuk mewujudkan suasana belajar dan proses pembelajaran agar peserta didik secara aktif mengembangkan potensi dirinya untuk memiliki kekuatan spiritual keagamaan, pengendalian diri, skepribadian, kecerdasan, akhlak mulia, serta ketrampilan yang diperlukan dirinya, masyarakat, bangsa, dan negara. Ini menjadi pekerjaan rumah tersendiri bagi pemerintah negara Indonesia untuk melangsungkan pembelajaran tanpa terjadinya tatap muka serta menimbulkan kerumunan. Pada akhirnya pemerintah mengeluarkan kebijakan yang diatur dalam Surat Edaran Nomor 4 Tahun 2020 Tentang Pelaksanaan Kebijakan Pendidikan Dalam Masa Darurat Penyebaran Covid-19.

Kebijakan ini mengharapkan siswa masih dapat mendapatkan pemenuhan hak peserta didik untuk mendapatkan layanan pendidikan selama darurat Covid-19. Belajar dari rumah merupakan keputusan pemerintah untuk solusi pendidikan dari masa pandemi yang berlangsung. Adanya fenomena ini memicu ide penggunaan teknologi digital sebagai alternatif untuk mengatasi terhambatnya pendidikan akibat dari pembatasan kegiatan berkerumun atau berkumpul. Habibah dkk (2020) menyebutkan dengan adanya perkembangan teknologi dan informasi digunakan sebagai media yang dapat menjadi solusi manusia dalam hal pekerjaan terutama saat pandemi Covid-19.

Teknologi digital dianggap mampu menjadi solusi untuk keberlangsungan pendidikan pada masa pandemi. Karena pendidikan pada dasarnya adalah suatu proses bermakna dalam kelangsungan pembentukan manusia menjadi makhluk untuh melalui proses belajar. Pendidikan merupakan aspek yang penting bagi kehidupan. Pendidikan memiliki posisi yang fundamental bagi pembangunan diri manusia. Pendidikan merupakan cara manusia untuk dapat berkembang dan bertahan hidup. Melalui pendidikan manusia mampu beradaptasi terhadap perubahan dengan menjawab setiap tantangan masalah yang muncul dalam setiap perkembangan zaman (Sugiarti dan Andalas, 2020).

Perkembangan teknologi memberikan peluang terhadap terciptanya metode-metode baru dalam pembelajaran. Hal itu dikarenakan terknologi mampu memberikan fasilitas yang membuat sebuah pendidikan menjadi lebih bermakna, efektif, dan efisien. Salah satu contohya yaitu pemanfaatan ternologi digital dalam pendidikan. Penggunaan teknologi digital pada masa pandemi memberikan pengaruh besar pada dunia pendidikan yang memasuki budaya baru, yaitu digitalisasi dunia pendidikan. Hal itu didasarkan pada 
3841 Tantangan Digitalisasi Pendidikan bagi Orang Tua dan Anak Di Tengah Pandemi Covid-19 di Desa Bendanpete - Rizky Wulandari, Santoso, Sekar Dwi Ardianti

DOI : https://doi.org/10.31004/edukatif.v3i6.1312

banyaknya fenomena penggunaan produk teknologi digital sebagai sarana dalam sistem pelaksanakan pendidikan. Menjadikan pendidikan menjadi lebih dinamis dan fleksibel dalam pengembangannya (Wayhono dkk, 2020).

Pada penelitian terdahulu, telah dilakukan penelitian mengenai pengaruh literasi digital terhadap peningkatan pembelajaran siswa di SMP N 6 Banda Aceh oleh Bella Elpira (2018) yang membahas tentang pengaruh literasi digital terhadap peningkatan pembelajaran siswa. Penelitian terdahulu mengenai pemanfaatan teknologi informasi dalam pembelajaran tingkat sekolah dasar pada masa pandemi Covid-19 oleh Ni Komang Suni Astini (2020) yang membahas tentang penggunaan teknologi dalam pembelajaran selama pandemi Covid-19 terlaksana secara efektit tetapi masih terbatas karena faktor pengetahuan orang tua mengenai aplikasi untuk belajar daring. Penelitian terdahulu tentang studi eksploratif dampak pandemi Covid19 terhadap proses pembelajaran online di sekolah dasar oleh Purwanto dkk (2020) yang membahas tentang dampak yang dialami oleh guru, anak serta orang tua selama pandemi. Namun belum ada penelitian mengenai bentuk, tantangan serta dampak digitalisasi pendidikan di tengah pandemi Covid-19. Keterbaharuan dalam penelitian ini terletak dalam bentuk, tantangan serta dampak pembelajaran digital di tengah pandemi Covid19.

Berdasarkan hasil observasi dan wawancara awal yang telah dilaksanakan diketahui bahwa pembelajaran daring (online) membuat peserta didik dan orang tua bingung dan merasa kesulitan. Hal ini dikarenakan dalam dua proses penting pembelajaran tidak berjalan seperti semestinya. Pertama dalam penyerapan materi yang sedikit. Ketika guru kelas memberikan tugas kepada siswa untuk mempelajari materi yang ditujukan, siswa hanya membaca materi sekilas sehingga membuat daya serap materi menjadi rendah. Yang kedua adalah proses pengerjaan tugas. Pada kali ini peran orang tua lebih dominan dan lebih aktif daripada siswa yang mendapatkan tugas untuk mencari jawaban, sehingga siswa tersebut hanya mendapatkan jawaban, bukan pemahaman tentang bagaimana maksud dari tugas yang dikerjakan. Dominasi orang tua dalam pengerjaan tugas ini dikarenakan mereka yang tidak ingin mendengar anaknya mengeluh tentang ketidakpahaman mempelajari materi atau mengerjakan tugas disaat para orang tua sudah lelah setelah pulang dari kerja. Akibatnya para orang tua mengambil alih tugas yang seharusnya dikerjakan oleh siswa tersebut.

Kepemilikan smartphone juga menjadi masalah dalam pembelajaran daring. Beberapa peserta didik tidak memiliki ponsel pribadi yang seharusnya digunakan untuk mendukung digitalisasi pendidikan. Jika ada grup kelas di aplikasi Whatsapp yang digunakan untuk membagi informasi oleh guru, maka orang tua merekalah yang berada di dalam grup tersebut. Sedangkan rata-rata orang tua siswa sibuk bekerja di dari pagi hingga sore sehingga mereka menjadi tertinggal oleh materi maupun tugas yang sudah diberikan oleh wali kelas mereka. Wahyono dkk (2020) sekolah dan guru hanya memberi tugas secara beruntun sesuai rencana pelajaran dan materi pelajaran dalam kondisi non-pandemi.

Berdasarkan uraian diatas, maka tujuan penulisan artikel ini adalah untuk mengetahui bentuk digitalisasi pendidikan bagi orang tua dan anak di tengah pandemi Covid-19 di Desa Bendanpete, untuk mengetahui tantangan digitalisasi pendidikan bagi orang tua dan anak di tengah pandemi Covid-19 di Desa Bendanpete serta untuk untuk mengetahui dampak digitalisasi pendidikan bagi orang tua dan anak di tengah pandemi Covid-19 di Desa Bendanpete. Tujuan dari penelitian ini adalah untuk mengetahui bentuk, tantangan serta dampak digitalisasi pendidikan bagi orang tua dan anak di tengah pandemi Covid-19.

\section{METODE PENELITIAN}

Penelitian ini dilaksanakan di Desa Bendanpete Kecamatan Nalumsari Kabupaten Jepara. Penelitian dilaksanakan selama 1 bulan dari bulan Juli. Penelitian ini menggunakan pendekatan kualitatif fenomenologi yang berfokus pada hanya sebuah kasus dan pengalaman subyek peneitian sehingga didapati sebuah bukti nyata dan alami sehingga dapat menjawab fokus penelitian. 
Subjek penelitian terdiri dari orang tua yang memiliki anak usia 6-12 tahun serta anak berusia 6-12 di Desa Bendanpete. Sumber primer data penelitian ini adalah orang tua dan anak. Sedangkan sumber sekunder berasal dari dokumentasi, cacatan wawancara dan data pendukung lainnya. Penelitian ini menggunakan teknik pengumpulan data berupa observasi, wawancara serta dokumentasi. Teknik analisis data pada penelitian ini menggunakan cara Miles dan Huberman yaitu dengan cara mereduksi data, menyajikan data kemudian membuat kesimpulan yang menjawab rumusan masalah.

Tabel 1. Sumber Data Orang Tua

\begin{tabular}{clccc}
\hline No & $\begin{array}{c}\text { Nama } \\
\text { Orang Tua }\end{array}$ & Umur & $\begin{array}{c}\text { Tingkat } \\
\text { Pendidikan }\end{array}$ & Pekerjaan \\
\hline \multirow{2}{*}{ 1. } & Bapak : D & 45 & SMP & Pekerja Bangunan \\
\cline { 2 - 5 } & Ibu : S & 35 & SMP & Buruh Pabrik \\
\hline \multirow{2}{*}{2.} & Bapak: DA & 45 & D2 & Wiraswasta \\
\cline { 2 - 5 } & Ibu : K & 42 & SMA & Wiraswasta \\
\hline \multirow{2}{*}{3.} & Bapak: KM & 43 & D2 & Perangkat Desa \\
\cline { 2 - 5 } & Ibu : HL & 42 & S1 & Guru Sekolah Dasar \\
\hline \multirow{2}{*}{4.} & Bapak: : & 39 & S1 & Wiraswasta \\
\cline { 2 - 5 }$:$ Ibu $:$ USP & 34 & S1 & Guru Sekolah Dasar \\
\hline
\end{tabular}

Tabel 2. Sumber Data Peserta Didik/ Anak

\begin{tabular}{llccc}
\hline No & Nama & Jenis Kelamin & Kelas & $\begin{array}{c}\text { Hasil Belajar } \\
\text { Selama Pandemi }\end{array}$ \\
\hline 1. & MK & Laki-laki & 5 & Rendah \\
\hline 2. & RA & Perempuan & 6 & Tinggi \\
\hline 3. & FA & Laki-laki & 6 & Sedang \\
\hline 4. & ABP & Perempuan & 6 & Sedang \\
\hline
\end{tabular}

\section{HASIL DAN PEMBAHASAN PENELITIAN}

\section{Bentuk Digitalisasi Pendidikan Bagi Orang Tua dan Anak di Tengah Pandemi Covid-19 di Desa Bendanpete}

Teknologi informasi dan komunikasi memberikan kemudahan serta membantu tenaga pendidik, anak serta orang tua dalam pembelajaran, terlebih dalam kondisi di tengah pandemi Covid-19. Teknologi informasi dan komunikasi dapat digunakan dalam berbagai kepentingan: mulai dari secara pasif untuk kepentingan presentasi, mencari informasi, berinteraksi dan berkomunikasi, sampai kepada yang paling aktif, untuk menghasilkan suatu produk. Akan tetapi digitalisasi pendidikan nampaknya masih sulit untuk diterapkan, apalagi dengan bentuk pembelajaran yang menjadi satu arah saja.

"Guru hanya memberikan tugas lewat group chat WhatsApp". (Anak RA, 1 Juli 2021).

"Guru saya selalu membagi tugas di grup WA. Tetapi beberapa kali guru agama saya membagikan tugas lewat google form”. (Anak ABP, 1 Juli 2021).

"Anak saya hanya belajar lewat group chat WhatsApp saja". (Ibu K, 1 Juli 2021).

"Kebanyakan gurunya memberikan tugas lewat group chat WA, tetapi gurunya juga sesekali memberikan tugas lewat google form”. (Ibu USP, 1 Juli 2021).

Bentuk digitalisasi pendidikan ditengah pandemi berupa pembelajaran tidak langsung. Hampir semua guru menggunakan aplikasi WhatsApp dalam proses pembelajaran. Akan tetapi penggunaan media pembelajaran tidak hanya menggunakan group chat WhatsApp saja, tetapi juga menggunakan media google form. Pemilihan penggunaan media pembelajaran yang tepat akan menambah antusias anak selama mengikuti kegiatan pembelajaran. Kaitannya dengan hasil penelitian tersebut, sesuai dengan penelitian yang dilakukan 
3843 Tantangan Digitalisasi Pendidikan bagi Orang Tua dan Anak Di Tengah Pandemi Covid-19 di Desa Bendanpete - Rizky Wulandari, Santoso, Sekar Dwi Ardianti

DOI : https://doi.org/10.31004/edukatif.v3i6.1312

oleh Farell (2021) yang menyatakan bahwa hasil belajar dan tingkat pemahaman peserta didik memiliki perbedaan yang penting antara kelas yang menggunakan bentuk pembelajaran asynchronous dengan kelas yang menggunakan bentuk pembelajaran synchronous.

\section{Tantangan Digitalisasi Pendidikan Bagi Orang Tua dan Anak di Tengah Pandemi Covid-19 di Desa Bendanpete}

\section{Bagi Anak \\ Gagap Teknologi}

Pemilihan pembelajaran daring menggunakan teknologi informasi dan komunikasi menjadi pilihan di tengah pandemi Covid-19. Situasi yang terjadi sekarang ini menuntut keterlibatan orang tua secara lebih maksimal untuk mendampingi anak dalam kegiatan belajar. Peran orangtua sangatlah penting dalam mendampingi belajar anak ketika di rumah yang saat ini pembelajaran berlangsung secara daring (Risalah dkk, 2020).

"Saya hanya bisa sebatas membuka grup WhatsApp dan bermain game online". (Anak MK, 1 Juli 2021).

Penggunaan media teknologi dan informasi ditengah pandemi merupakan satu-satunya jalan agar pendidikan dapat terlaksana. Akan tetapi hal ini menjadikan tantangan tersendiri bagi tiap tingkatan pendidikan. Terutama pada tingkat sekolah dasar yang mereka belum mampu untuk menggunakan teknologi berbasis online. Kaitannya dengan hasil penelitian tersebut, sesuai dengan penelitian yang dilakukan oleh Salsabila dkk (2021) yang menyatakan bahwa anak kurang menguasai penggunaan teknologi merupakan sebuah tugas sekaligus tantangan baru bagi orang tua untuk mengajari sekaligus melatih anaknya dalam menggunakan sarana teknologi informasi dan komunikasi agar dapat mengikuti pembelajaran daring dengan baik.

\section{Bagi Orang Tua}

\section{Ketersediaan Paket Data}

Dalam pelaksanaan pembelajaran daring tentunya tidak dapat lepas dari peran teknologi informasi dan komunikasi. Teknologi dapat mempermudah segala kebutuhan yang diperlukan selama proses belajar mengajar (Salsabila dkk, 2020). Pembelajaran daring dapat terlaksana dengan baik apabila perangkat gadget tersambung dengan koneksi internet. Hal ini menjadikan suatu tantangan tersendiri bagi orang tua sebagai pihak yang berperan sebagai fasilitator anak selama pembelajaran daring.

"Semenjak belajar daring, setiap 2 minggu sekali pasti membeli paket kuota. Bahkan pernah seminggu sekali membeli paket data”. (Ibu K, 1 Juli 2021).

"Biaya untuk membeli paket data membengkak. Karena selain digunakan untuk menonton video yang biasanya di share di group chat WhatsApp, browsing seperti itu”. (Ibu S, 1 Juli 2021).

Penggunaan kuota internet meningkat semenjak dilaksanakannya digitalisasi pendidikan. Tingginya penggunaan kuota internet oleh anak selama pembelajaran daring membuat suatu tantangan tersendiri bagi orang tua. Terlebih dengan pekerjaan yang berbeda membuat pendapatan per orang tua berbeda. Orang tua merasa terbebani untuk menyediakan sarana dan prasana, terlebih pada penyediaan kuota untuk pembelajaran daring. Orang tua merasa pembelajaran daring membuat pengeluaran untuk membeli kuota meningkat daripada biasanya. Kaitannya dengan hasil penelitian tersebut, sesuai dengan penelitian yang dilakukan oleh Purwanto (2020) menyatakan bahwa adanya penambahan biaya ekstra pembelian kuota internet bertambah akibat dari teknologi online yang memerlukan koneksi jaringan ke internet dan kuota oleh karena itu tingkat penggunaaan kuota internet akan bertambah dan akan menambah biaya pengeluaran orang tua. 
3844 Tantangan Digitalisasi Pendidikan bagi Orang Tua dan Anak Di Tengah Pandemi Covid-19 di Desa Bendanpete - Rizky Wulandari, Santoso, Sekar Dwi Ardianti

DOI : https://doi.org/10.31004/edukatif.v3i6.1312

\section{Manajemen Waktu}

Sudah sepatutnya orang tua berperan serta di dalam penyelenggaraan pembelajaran daring. Namun realisasinya masih jauh dari harapan. Masih banyak orang tua yang belum terlibat dan memiliki andil dalam penyelengaraan pembelajaran daring. Seperti halnya kesibukan orang tua dalam bekerja ataupun sikap orang tua yang tanpa sengaja tidak memberikan dukungan dan partisipasi terhadap pembelajaran daring anaknya (Imtinan, Afifulloh, Sudrajat, 2021).

"Kendalanya pasti ada. Saya orang tua tunggal yang setiap hari masuk kerja. Kemudian kalau saya pulang masih harus bersih-bersih rumah, jadi kalau malam badan saya sudah lelah. Di tambah tugas anak belum selesai karena ada beberapa soal yang sulit, jadi mau tidak mau saya yang mengerjakan tugas itu daripada anak saya merengek". (Ibu S, 1 Juli 2021).

"Saya mendapati beberapa kendala selama anak melaksanakan pembelajaran daring. Yang pertama karena saya dan suami saya sama-sama bekerja sehingga tidak bisa mendampingi anak secara langsung saat pembelajaran daring. Saya bisanya menanyakan tentang tugas maupun materi kepada anak saya setelah jam pembelajaran daring selesai." (Ibu USP, 1 Juli 2021).

Orang tua masih kesulitan membagi waktu untuk bekerja dan mendampingi anak selama pembelajaran daring. Orang tua cenderung memiliki kesibukan yang tinggi sehingga tidak dapat mendampingi belajar anak secara maksimal. Kaitannya dengan hasil penelitian tersebut, sesuai dengan penelitian yang dilakukan oleh Purwanto dkk (2020) yang menyatakan bahwa selama permbelajaran daring orang tua harus menyediakan waktu lebih kepada anak dalam mendampingi belajar daring yang mengakibatkan mereka harus membagi waktu untuk mendampingi anak-anaknya selama daring dan waktu untuk pekerjaan sehari-hari.

\section{Perubahan Pola Belajar}

Keputusan pemerintah negara Indonesia tentang kebijakan dari PSBB menjadi kondisi new normal dengan protokol Covid-19 yang ketat berdasarkan kebijakan social distancing yang menjadi dasar pelaksanaan belajar dari rumah dengan pemanfaatan teknologi informasi dan komunikasi sebagai media pembelajaran. Hal ini membuat kaget seluruh sektor kehidupan, tidak terkecuali sektor pendidikan dimana baik tenaga didik, peserta didik, maupun orang tua merasa kaget adanya perubahan secara mendadak. Orang tua kini memiliki tugas ganda untuk menjadi orang yang mencari nafkah serta menjadi guru anak di rumah.

"Yang kedua saya tidak terbiasa dengan pola belajar yang sekarang mbak. Walaupun profesi saya sendiri seorang guru tapi saya juga perlu adaptasi dengan keadaan. Jadi anak banyak tugas begini ya saya ikut pusing." (Ibu USP, 1 Juli 2021).

Proses pembelajaran yang biasanya dilangsungkan di sekolah kini menjadi dilaksanakan dari rumah dengan orang tua yang berperan sebagai pengganti peserta didik menjadikan orang tua kebingungan dengan adanya perubahan pola belajar. Kaitannya dengan hasil penelitian tersebut, sesuai dengan penelitian yang dilakukan oleh (Astini, 2020) yang menyatakan bahwa sebagian besar mahasiswa tidak pernah melakukan pembelajaran daring. Data ini menunjukkan bahwa mahasiswa belum siap untuk melakukan pembelajaran daring karena akan berdampak pada budaya akademik yang memuat nilai, sikap, pengetahuan dan keterampilan, serta kesiapan sarana dan prasana yang berkaitan dengan pencarian informasi di kalangan mahasiswa.

\section{Dampak Digitalisasi Pendidikan Bagi Orang Tua dan Anak di Tengah Pandemi Covid-19 di Desa Bendanpete}


3845 Tantangan Digitalisasi Pendidikan bagi Orang Tua dan Anak Di Tengah Pandemi Covid-19 di Desa Bendanpete - Rizky Wulandari, Santoso, Sekar Dwi Ardianti

DOI : https://doi.org/10.31004/edukatif.v3i6.1312

\section{Bagi Anak}

\section{Dampak Positif}

\section{Tersedianya Media Massa Untuk Mencari Informasi}

Teknologi informasi dan komunikasi memiliki peran penting selama pembelajaran daring berlangsung. Salsabila dkk (2020) menyatakan bahwa teknologi informasi dan komunikasi menjadi media yang mendukung sistem pembelajaran yang ada dalam pembelajaran. Dengan adanya teknologi informasi dan komunikasi menjadikan pembelajaran daring dapat terlaksana di tengah pandemi Covid-19. Tersedianya informasi serta media penunjang pembelajaran lainnya sebagai penunjang pendidikan memiliki dampak yang positif selama pembelajaran daring. Berikut merupakan hasil wawancara yang peniliti lakukan terhadap anak tentang dampak positif digitalisais pendidikan.

"Kalau mengerjakan tugas terus males baca buku gitu bisa cari langsung di internet". (Anak FA, 1 Juli 2021).

"Enaknya itu kalau ada soal yang enggak tahu jawabannya bisa browsing langsung di internet". (Anak RA 1 Juli 2021).

Dengan adanya digitalisasi pendidikan anak mendapatkan dampak positif yaitu tersedianya media massa untuk mencari informasi yang lebih luas yang dibutuhkan. Penggunaan browser seperti google menjadi solusi bagi anak-anak untuk menyelesaikan tugasnya secara mandiri. Anak merasa penggunaan media massa memudahkan dalam pengerjaan tugas sehingga mereka dapat belajar mandiri dalam menyelesaikan tugas mereka. Kaitannya dengan hasil penelitian tersebut, sesuai dengan penelitian yang dilakukan oleh Salsabila dkk (2020) yang menyatakan bahwa teknologi membantu anak dalam memperoleh materi pelajaran yang kemungkinan tidak dapat di peroleh selama pembelajaran daring berlangsung dengan mengakses berbagai macam website serta aplikasi.

\section{Waktu Belajar Menjadi Fleksibel}

Pembelajaran daring masih menuntut baik guru maupun anak untuk mencapai kompetensi dasar walaupun ada wabah pandemi Covid-19. Oleh sebab itu pendekatan pembelajaran yang fleksibel dirancang dengan menggunakan berbagai metode untuk anak selama belajar dari rumah (Rifa'ie, 2020). Hal ini bertujuan untuk memberikan kesempatan kepada anak untuk dapat mengakses informsai yang dibutuhkan. Berikut merupakan hasil wawancara dengan anak yang merasakan selama pembelajaran daring waktu belajar menjadi lebih fleksibel.

"Bisa menyimak guru di grup sambil tiduran". (Anak MK, 1 Juli 2021).

"Dampak positif pembelajaran daring itu pengumpulan tugas tidak harus langsung". (Anak ABP, 1 Juli 2021).

Dampak positif dari digitalisasi pendidikan di tengah pandemi adalah waktu belajar menjadi fleksibel. Anak dapat mengikuti proses pembelajaran daring dimana saja dan kapan saja. Anak menjadi memiliki memiliki waktu untuk mengerjakan tugas sebaik mungkin sebelum di kumpulkan kepada gurunya. Pelaksanaan pembelajaran daring memungkinkan baik siswa dan guru melaksanakan pembelajaran daring dari rumah. Anak dapat menerima maupun mengumpulkan tugas yang sudah diberikan tanpa harus bertatap muka di sekolah. Kaitannya dengan hasil penelitian tersebut, sesuai dengan penelitian yang dilakukan oleh Anugrahana (2020) yang menyebutkan bahwa pembelajaran daring memiliki fleksibilitas waktu dan tempat. Fleksibilitas yang disebabkan oleh pembelajaran daring menyebabkan anak dapat menghemat waktu dan dapat dilaksanakan kapan saja.

\section{Dampak Negatif}

\section{Kesulitan Memahami Materi}

Memahami materi pelajaran merupakan tujuan utamanya sebuah pembelajaran berlangsung. Akan tetapi terbatasnya ruang gerak akibat pandemi Covid-19 membuat terbatasnya pendidikan berpengaruh pada 
3846 Tantangan Digitalisasi Pendidikan bagi Orang Tua dan Anak Di Tengah Pandemi Covid-19 di Desa Bendanpete - Rizky Wulandari, Santoso, Sekar Dwi Ardianti

DOI : https://doi.org/10.31004/edukatif.v3i6.1312

pemahaman pengetahuan materi yang akan diajarkan. Berikut merupakan hasil wawancara dari anak yang merasakan sulit memahami materi selama pembelajaran daring:

"Pelajarannya tidak dijelaskan secara mendetail oleh guru”. (Anak RA, 1 Juli 2021).

"Saya menjadi tidak paham materi karena guru hanya memberikan tugas tanpa adanya penjelasan dari guru. Pemberian materi yang sangat banyak tanpa adanya penjelasan membuat saya kadang menguasai materi kadang tidak paham sama sekali”. (Anak ABP, 1 Juli 2021).

"Materi hanya diberikan secara sekilas, jadi saya tidak paham materi pelajarannya". (Anak MK, 1 Juli 2021).

Adanya digitalisasi pendidikan membuat anak kesulitan dalam belajar, terutama dalam pemahaman materi. Kurang efektifnya peran guru membuat siswa merasa kesulitan akan pemahaman materi. Padahal seharusnya proses digitlisasi pendidikan berjalan persis seperti pembelajaran tatap muka dimana guru memiliki peran yang besar dalam kelas. Kaitannya dengan hasil penelitian tersebut, sesuai dengan penelitian yang dilakukan oleh Arifin (2020) yang menyatakan bahwa kesulitan yang dihadapi oleh anak selama pembelajaran daring yakni susah dalam menerima materi karena terdapat sebagian besar guru memberikan tugas tanpa memberikan penjelasan materi, terkadang guru memberikan tugas dan batasan waktu yang bersamaan dengan tugas lainnya.

\section{Munculnya Sikap Malas Belajar}

Sudah satu tahun lebih negara Indonesia menggunakan sistem pembelajaran daring dengan media teknologi informasi dan komunikasi. Selama itu pula berbagai masalah mulai muncul akibat pembelajaran daring ini. Puspitasari (2020) menyatakan bahwa pelaksanaan pembelajaran daring membawa dampak kepada siswa, dampak yang dialami oleh anak yaitu mereka merasa sangat jenuh dan bosan akan pembelajaran. Semangat dan antusias yang ditunjukkan oleh anak untuk mengikuti pembelajaran daring semakin harinya semakin menurun.

"Tugasnya kebanyakan membuat saya jadi malas mengerjakan karena selain banyak juga susah susah. Ngerjain tugas kalau mepet waktu ngumpulin. Kalau enggak ya enggak saya kerjain”. (Anak MK, 1 Juli 2021).

"Saya jadi malas belajar, karena banyaknya tugas yang di berikan jadi banyak tugas yang terbengkalai. Materinya tidak dijelaskan oleh guru secara maksimal”. (Anak RA, 1 Juli 2021).

Pengerjaan tugas yang dilakukan sepenuhnya dirumah membuat anak menganggap bahwa tugas yang diberikan oleh guru sangat banyak. Hal ini berbeda dengan pemebelajaran secara tatap muka yang dilakukan didalam kelas yang mana pemberian tugas diberikan menjadi dua yaitu tugas diberikan selama pembelajaran di sekolah serta tugas yang diberikan untuk dijadikan sebagai pekerjaan rumah. Padahal tugas yang diberikan kepada anak sama bahkan tidak jarang lebih sedikit daripada saat pembelajaran secara tata muka didalam kelas. Kaitannya dengan hasil penelitian tersebut, sesuai dengan penelitian yang dilakukan oleh Fahruni dan Wiryosutomo (2021) yang menyebutkan anak malas belajar disebabkan oleh faktor internal dan faktor eksternal. Factor internal dari anak seperti anak yang tidak paham akan materi yang diberikan, anak mulai jenuh dengan pembelajaran daring serta efek dari pengerjaan tugas yang ditunda sehingga menyebabkan penumpukan tugas sehingga menyebabkan semangat pembelajaran daring anak hilang. Sedangkan factor eskternal pemicu malas belajar adalah sarana dan prasana yang kurang memadai.

\section{Penyalahguaan Teknologi Selama Pembelajaran Daring}

Adanya pandemi Covid-19 mnejadikan pendidikan anak dilaksanakan dengan jarak jauh. Pembelajaran jarak jauh dengan memanfaatkan teknologi informasi dan komunikasi yang sudah tersedia sehingga baik anak maupun orang tua tetap dapat berinteraksi dengan tenaga pendidik. (Iftitah dan Anawaty, 2020) menyatakan bahwa dalam implementasi pembelajaran daring tidak selalu berjalan lancar. Keluhan yang datang dari berbagai pihak seperti tenaga pendidik, anak, maupun orang tua pasti ada.

"Kalau enggak ada tugas dari guru ya saya main game online”. (Anak FA, 1 Juli 2021). 
3847 Tantangan Digitalisasi Pendidikan bagi Orang Tua dan Anak Di Tengah Pandemi Covid-19 di Desa Bendanpete - Rizky Wulandari, Santoso, Sekar Dwi Ardianti

DOI : https://doi.org/10.31004/edukatif.v3i6.1312

"Saya bosan kalau setiap hari di rumah. Jadi saya main ke rumah temen saya buat main game online bareng”. (Anak MK, 1 Juli 2021).

Digitalisasi pendidikan menyebabkan penyalahgunaan teknologi ketika belajar daring dengan cara bermain game online. Orang tua tidak dapat mendampingi anak belajar karena tuntutan pekerjaan membuat anak menggunakan kesempatan ini untuk mencari kesenangan sendiri. Padahal jika anak berada di kelas tinggi yang mana semakin banyak materi yang harus dipelajari dan dikuasai untuk bekal menuju jenjang pendidikan yang lebih tinggi. Hal ini sudah pasti akan berdampak kepada tingkat kognisi anak. Kaitannya dengan hasil penelitian tersebut, sesuai dengan penelitian yang dilakukan oleh Prawanti dan Sumarni (2020) yang menyatakan bahawa pembelajaran secara daring mengharuskan anak menggunakan teknologi informasi dan komunikasi sebagai penunjang proses pembelajaran. Keadaan seperti itu dan juga di dukung dengan orang tua yang kurang memperhatikan proses belajar peserta didik sehingga memberikan gadget pribadi kepada anak dapat dijadikan anak waktu untuk bermain game online daripada mengerjakan tugas yang diberikan oleh guru. Game online menjadikan anak menunda-nunda waktu untuk mengerjakan tugas.

\section{Munculnya Sikap Cuek}

Dalam proses belajar, tidak hanya melibatkan kemampuan akademik saja, tetapi juga melibatkan aspekaspek seperti emosi, interaksi sosial, dan perkembangan kepribadian. Yang mana perubahan tersebut timbul akibat dari dari aktivitas individu melakukan latihan dan pengalaman. Sehingga anak dikatakan belajar jika sudah adanya perubahan baik secara kognitif, afektif, maupun psikomotorik. Namun adanya pandemi Covid19 membuat proses pembelajaran yang ideal tersebut menjadi terhalang. Sehingga sudah pasti aspek non akademik paling terkena dampaknya.

"Semenjak pembelajaran daring saya menjadi cuek dengan keadaan sekitar. Soalnya main $h p$ itu menyenangkan, apalagi main game”. (Anak FA, 1 Juli 2021).

"Saya merasa tidak bisa bersosialisasi dengan teman-teman sehingga membuat saya menjadi tidak peka dengan keadaan sekitar”. (Anak ABP, Wawancara 1 Juli 2021).

Perkembangan teknologi dan komunikasi membuat anak menjadi terlena dengan segala fitur yang disediakan oleh menyebabkan rasa sosialnya hilang. Hal ini menjadi hal yang perlu diperhatikan baik bagi orang tua maupun tenaga pendidik. Perkembangan sosial emosional pada anak kelas tinggi seharusnya berada pada tahap anak mulai mencari perhatian kepada lingkungan sekitar, mulai mengerti rasa tanggung jawab. Akan tetapi karena adanya pandemi yang mengharuskan anak belajar dirumah menyebabkan perkembangan sosial emosional anak menjadi terganggu. Kaitannya dengan hasil penelitian tersebut, sesuai dengan penelitian yang dilakukan oleh Kusuma dan Sutapa (2020) yang menyatakan bahwa pembelajaran daring yang diakibatkan oleh adanya covid-19 tentu saja berpengaruh pada perilaku sosial emosional pada anak yaitu anak kurang bersikap kooperatif karena anak jarang bermain bersama, kurangnya bersosialisasi dengan teman terbatasi adanya belajar dirumah, emosi anak yang menjadi naik turun, anak merasa rindu teman dan guru, dan anak juga tercatat mengalami kekerasan verbal karena proses belajar yang tidak lazim.

\section{Bagi Orang Tua}

\section{Dampak Positif}

\section{Dapat Memantau Aktivitas Anak}

Proses pembelajaran daring pada tingkat sekolah dasar memang masih memperlukan pendampingan dari orang tua. Selain itu pendampingan juga sebagai upaya agar proses pembelajaran dapat berjalan sesuai dengan tujuan pembelajaran yang telah ditentukan. Kusumaningrum dkk (2020) menyatakan keberhasilan proses pembelajaran juga dipengaruhi oleh orang yang mendampingi anak ketika melaksanakan pembelajaran daring.

"Karena belajar dari rumah ini jadinya saya dan istri saya ikut membimbing anak belajar, dan garagara itu saja jadi bisa memantau bagaimana aktivitas belajar anak saya”. (Bapak KM, 1 Juli 2021). 
3848 Tantangan Digitalisasi Pendidikan bagi Orang Tua dan Anak Di Tengah Pandemi Covid-19 di Desa Bendanpete - Rizky Wulandari, Santoso, Sekar Dwi Ardianti

DOI : https://doi.org/10.31004/edukatif.v3i6.1312

"Enaknya ya bisa memantau aktivitas anak. Jadi kalau anaknya lagi browsing gitu kita bisa memantau apakah anaknya beneran cari materi atau malahan cari hal diluar pembelajaran. Terus jadi bisa memastikan jawaban tugas anak sudah benar atau masih ada yang perlu dibenahi sebelum dikumpulkan”. (Ibu K, 1 Juli 2021).

"Enaknya pembelajaran daring ya bisa memantau tugas anak mbak. Apakah tugasnya masih ada yang keteteran atau udah dikerjakan semua". (Ibu USP, 1 Juli 2021).

Dengan adanya digitalisasi pendidikan membuat orang tua lebih gampang untuk memantau aktivitas anak. Kegiatan pembelajaran yang dilakukan di rumah bersama dengan orang tua menyebabkan orang tua dapat memantau bagaimanan perkembangan akademik anak. Kaitannya dengan hasil penelitian tersebut, sesuai dengan penelitian yang dilakukan oleh Kusumaningrum dkk (2020) yang menyatakan bahwa pembelajaran anak sekola dasar tidak dapat lepas dari peran orang tua sebagai guru di rumah. Orang tua memiliki tanggung jawab penuh akan keberhasilan proses pembelajaran anak. aktivitas orang tua yang biasanya dilakukan selama memantau aktivitas anak adalah dengan memeriksa tugas, memeriksa penyelesaian tugas yang telah dikerjakan serta mengevalusasi pemahaman materi anak.

\section{Dampak Negatif}

\section{Kurang Memahami Materi Anak}

Pandemi Covid-19 menyebabkan dikeluarkan kebijakan pembelajaran dari rumah dengan sistem daring menggunakan teknologi informasi dan komunikasi sebagai medianya. Tidak hanya anak yang merasa kebingungan dengan adanya perubahan mendadak dalam sektor pendidikan ini, tetapi orang tua juga ikut kebingungan dengan adanya pembelajaran daring. Akibatnya orang tua harus beradaptasi dengan keadaan terlebih dahulu. orang tua juga harus beradaptasi dengan peran ganda yang dimiliki. Pembelajaran daring yang jauh dari guru sebagai orang yang menyampaikan materi pembelajaran membuat peran orang tua bertambah yakni sebagai guru di rumah.

"Dampaknya itu saya kesulitan di memahami materi anak. Karena ya materi pelajaran dulu dan sekarang berbeda. Dan ketika anak mengerjakan tugas sering terus di cari di buku lksnya gak ketemu ya saya pakai cara browsing. Tapi cara ini juga buat bingung karena biasanya ada dua jawaban yang berbeda, jadi saya bingung harus memilih jawaban yang mana untuk tugas anak saya”. (Ibu K, 1 Juli 2021).

"Materinya sulit sulit mbak. Anaknya saja tidak paham, apalagi orang tuanya. Jadi makin bingung dengan materi pelajarannya." (Ibu S, 1 Juli 2021).

“Jujur saya mbak saya juga kurang memahami materi anak.” (Bapak KM, 1 Juli 2021).

Adanya digitalisasi pendidikan menyebabkan kesulitan bagi orang tua untuk memahami materi anak. Orang tua merasa bahwa materi pelajaran anak zaman sekarang lebih sukar dan berbeda dengan materi pelajaran orang tua pada zaman dahulu sehingga orang tua kesulitan memahami materi anak. Tingkat pendidikan orang tua juga berpengaruh akan kemajuan akademik anak. Kaitannya dengan hasil penelitian tersebut, sesuai dengan penelitian yang dilakukan oleh Daheri dkk (2020) yang menuturkan bahwa kesulitan memahami materi anak wajar dialami oleh orang tua karena latar belakang orang tua yang sangat berbedabeda. Bagi orang tua yang berpendidikan tinggi membimbing anaknya belajar pada tingkat sekolah dasar masih cukup mudah. Itupun tidak pada semua mata pelajaran, pada mata pelajaran tertentu tetap saja orang tua tidak mudah mempelajari dan membimbing anaknya.

\section{Pengeluaran Membengkak}

Pelaksaan pembelajaran daring merupakan suatu hal yang baru dirasakan oleh para orang tua. Hal ini menjadikan orang tua lebih serius dalam menjalankan peran dan tugasnya kepada anak. terlebih pandemi Covid-19 membuat pergeseran peran yang seharusnya dilaksanakan guru di sekolah menjadi dilaksanakan oleh orang tua di rumah. Orang tua mempunyai peran sebagai fasilitator utama terhadap pembelajaran daring anak (Anggraeni, Fakhriyah, Ahsin, 2021). Sehingga dalam pelaksanaannya didapat beberapa kendala yang 
3849 Tantangan Digitalisasi Pendidikan bagi Orang Tua dan Anak Di Tengah Pandemi Covid-19 di Desa Bendanpete - Rizky Wulandari, Santoso, Sekar Dwi Ardianti

DOI : https://doi.org/10.31004/edukatif.v3i6.1312

dirasakan oleh orang tua. Salah satunya yakni pemenuhan biaya kuota internet anak yang menyebabkan pengeluaran orang tua menjadi membengkak.

"Ya tadi ya, selain anak kurang menguasai materi itu yang paling saya rasakan ya. Terus membengkaknya pengeluaran untuk membeli kuota internet”. (Bapak KM, 1 Juli 2021).

"Boros biaya untuk membeli kuota”. (Ibu K, 1 Juli 2021).

"Anak saya setiap minggu beli kuota terus, bikin saya pusing karena uang hasil kerjanya habis buat beli kuota”. (Ibu S, 1 Juli 2021).

Pembelajaran daring yang setiap hari dilaksanakan anak sebagai salah satu cara pemenuhan pendidikan di tengah pandemi. Mulai dari anak diberikan tugas untuk melihat video yang sudah dibagikan ataupun memfoto hasil tugasnya yang kemudian dikirimkan kepada gurunya sebagai bentuk pemenuhan tugas. Tentu aktivitas tersebut memakan kuota cukup banyak. Belum lagi ketika anak melakukan browsing di internet untuk menyelesaikan tugas. Kuota internet yang dibeli untuk kebutuhan internet menjadi meningkat dan banyak dari orang tua anak yang tidak siap untuk menambah anggaran dalam penyediaan jaringan internet selama pembelajaran daring. Kaitannya dengan hasil penelitian tersebut, sesuai dengan penelitian yang dilakukan oleh (Anggraeni, Fakhriyah, Ahsin (2021) yang menyatakan bahwa pembelajaran daring lebih membutuhkan banyak uang untuk membeli paket data. Penyediaan paket data membuat orang tua kesulitan karena keadaan ekonomi.

\section{KESIMPULAN}

Digitalisasi pendidikan di tengah pandemi Covid-19 tidak terlepas orang tua yang memiliki peran ganda di rumah dan anak sebagai peserta didik. Bentuk digitalisasi pendidikan di tengah pandemi di Desa Bendanpete adalah pembelajaran tidak sinkron (asyncrhonous learning). Tantangan digitalisasi pendidikan bagi anak adalah masih adanya anak yang gagap teknologi. Sedangkan tantangan bagi orang tua adalah tantangan pada ketersediaan paket data, majamen waktu serta perubahan pola belajar. Dampak digitalisasi pendidikan di tengah pandemi di Desa Bendanpete memiliki dampak positif dan negatif. Dampak positif bagi anak adalah tersedianya media massa untuk mencari informasi serta waktu belajar menjadi fleksibel. Sedangkan dampak negatif bagi anak adalah anak kesulitan memahami materi, menjadi malas belajar, penyalahgunaan teknologi selama pembelajaran daring, serta munculnya sikap cuek terhadap lingkungan sekitar. Adapun dampak positif digitalisasi pendidikan bagi orang tua adalah dapat memantau aktivitas belajar anak selama di rumah. Dampak negatif dari digitalisasi pendidikan adalah orang tua kesulitan memahami materi anak serta pengeluaran menjadi membengkka akibat untuk pemenuhan fasilitas anak.

\section{DAFTAR PUSTAKA}

Ainur Risalah, W Ibad, L Maghfiroh, M I Azza, S A Cahyani, \& Z A Ulfayati. (2020). Dampak Pandemi Covid-19 Terhadap Kegiatan Belajar Mengajar Di MI/SD (Studi KBM Berbasis Daring Bagi Guru Dan Siswa). JIEES: Journal Of Islamic Education At Elementary School, 1(1), 10-16. Https://Doi.Org/10.47400/Jiees.V1i1.5

Anggraeni, N., Fakhriyah, F., \& Ahsin, M. N. (2021). Peran Orang Tua Sebagai Fasilitator Anak Dalam Proses Pembelajaran Online Di Rumah 1. VIII(2), 105-117. Https://Doi.Org/10.30659/Pendas.8.2.105117

Anugrahana, A. (2020). Hambatan, Solusi Dan Harapan: Pembelajaran Daring Selama Masa Pandemi Covid19 Oleh Guru Sekolah Dasar. Scholaria: Jurnal Pendidikan Dan Kebudayaan, 10(3), 282-289. Https://Doi.Org/10.24246/J.Js.2020.V10.I3.P282-289

Arifin, H. N. (2020). Respon Siswa Terhadap Pembelajaran Dalam Jaringan Masa Pandemi Chovid-19 Di 
3850 Tantangan Digitalisasi Pendidikan bagi Orang Tua dan Anak Di Tengah Pandemi Covid-19 di Desa Bendanpete - Rizky Wulandari, Santoso, Sekar Dwi Ardianti

DOI : https://doi.org/10.31004/edukatif.v3i6.1312

Madrasah Aliyah Al-Amin Tabanan. Widya Balina, 53(9), 1689-1699.

Astini. (2020a). Pemanfaatan Teknologi Informasi Dalam Pembelajaran Tingkat Sekolah Dasar Pada Masa Pandemi Covid-19. Jurnal Lembaga Penjaminan Mutu STKIP Agama Hindu Amlapura, 11(2), 13-25.

Astini, N. K. S. (2020b). Tantangan Dan Peluang Pemanfaatan Teknologi Informasi Dalam Pembelajaran Online Masa Covid-19. Cetta: Jurnal Ilmu Pendidikan, 3(2), 241-255. Https://Doi.Org/10.37329/Cetta.V3i2.452

Daheri, M., Juliana, J., Deriwanto, D., \& Amda, A. D. (2020). Efektifitas Whatsapp Sebagai Media Belajar Daring. Jurnal Basicedu, 4(4), 775-783. Https://Doi.Org/10.31004/Basicedu.V4i4.445

Elpira, B. (2018). Pengaruh Literasi Digital Terhadap Peningkatan Pembelajaran Siswa Di SMP Negeri 6 Banda Aceh (Issue 21).

Fahruni, Findivia Egga Wiryosutomo, H. W. (2021). Analisis Faktor-Faktor Penyebab Perilaku Malas Belajar Daring Saat Pandemi Covid-19 Pada Siswa Kelas Xii Sma Negeri 1 Menganti Gresik. Jurnal BK UNESA, 12(2), 22-36.

Farell, G., Simatupang, W., \& Giatman, M. (2021). EDUKATIF : JURNAL ILMU PENDIDIKAN Analisis Efektivitas Pembelajaran Daring Pada SMK Dengan Metode Asynchronous Dan Synchronous. Edukatif: Jurnal Ilmu Pendidikan, 3(4), 1185-1190.

Habibah, R., Salsabila, U. H., Lestari, W. M., Andaresta, O., \& Yulianingsih, D. (2020). Pemanfaatan Teknologi Media Pembelajaran Di Masa Pandemi Covid-19. Trapsila: Jurnal Pendidikan Dasar, 2(02), 1. Https://Doi.Org/10.30742/Tpd.V2i2.1070

Hakim, L. (2016). Pemerataan Akses Pendidikan Bagi Rakyat Sesuai Dengan Amanat Undang-Undang Nomor 20 Tahun 2003 Tentang Sistem Pendidikan Nasional [Improving Access To Education As Mandated By Law No. 20, 2003 On National Education System]. Edutech: Jurnal Ilmu Pendidikan Dan Ilmu Sosial, 2(1), 53-64. Http://Jurnal.Umsu.Ac.Id/Index.Php/Edutech/Article/View/575

Hanifah Salsabila, U., Irna Sari, L., Haibati Lathif, K., Puji Lestari, A., \& Ayuning, A. (2020). Peran Teknologi Dalam Pembelajaran Di Masa Pandemi Covid-19. Al-Mutharahah: Jurnal Penelitian Dan Kajian Sosial Keagamaan, 17(2), 188-198. Https://Doi.Org/10.46781/Al-Mutharahah.V17i2.138

Herdiana, D. (2020). Social Distancing: Indonesian Policy Response To The Corona Virus. Jurnal Ilmu Administrasi, 17(1), 93-110.

Iftitah, S. L., \& Anawaty, M. F. (2020). Peran Orang Tua Dalam Mendampingi Anak Di Rumah Selama Pandemi Covid-19. JCE (Journal Of Childhood Education), 4(2), 71. Https://Doi.Org/10.30736/Jce.V4i2.256

Imtinan, F. T., Afifulloh, M., \& Sudrajat, A. (2021). VICRATINA : Jurnal Pendidikan Islam Volume 6 Nomor 4 Tahun 2021 E-ISSN: $2087-0678 X .6(4)$.

Kusuma, W. S., \& Sutapa, P. (2020). Dampak Pembelajaran Daring Terhadap Perilaku Sosial Emosional Anak. Jurnal Obsesi: Jurnal Pendidikan Anak Usia Dini, 5(2), 1635-1643. Https://Doi.Org/10.31004/Obsesi.V5i2.940

Kusumaningrum, B., Singgih Kuncoro, K., \& Astuti Arigiyati, T. (2020). Inventa: Jurnal Pendidikan Guru Sekolah Dasar Pendampingan Orangtua Dalam Pembelajaran Daring Di Sekolah Dasar: Evaluasi Pembelajaran Daring Selama Masa Pandemi Covid-19. INVENTA: Jurnal Pendidikan Guru Sekolah Dasar, 04(2), 145. Http://Jurnal.Unipasby.Ac.Id/Index.Php/Jurnal_Inventa

No, V., \& Mona, N. (2020). Konsep Isolasi Dalam Jaringan Sosial Untuk Meminimalisasi Efek Contagious (Kasus Penyebaran Virus Corona Di Indonesia). Jurnal Sosial Humaniora Terapan, 2(2), 117-125. Https://Doi.Org/10.7454/Jsht.V2i2.86

Pennington, T. (2020). Panduan Kesiapsiagaam Hadapi Virus Corona. Elex Media Komputindo.

Prawanti, L. T., \& Sumarni, W. (2020). Kendala Pembelajaran Daring Selama Pandemic Covid-19. Prosiding 
3851 Tantangan Digitalisasi Pendidikan bagi Orang Tua dan Anak Di Tengah Pandemi Covid-19 di Desa Bendanpete - Rizky Wulandari, Santoso, Sekar Dwi Ardianti

DOI : https://doi.org/10.31004/edukatif.v3i6.1312

Seminar Nasional Pascasarjana UNNES, 286-291.

Purwanto, A., Pramono, R., Asbari, M., Santoso, P. B., Wijayanti, L. M., Choi, C. H., \& Putri, R. S. (2020). Studi Eksploratif Dampak Pandemi COVID-19 Terhadap Proses Pembelajaran Online Di Sekolah Dasar. Edupsycouns: Journal Of Education, Psychology And Counseling, 2(1), 1-12. Https://Ummaspul.EJournal.Id/Edupsycouns/Article/View/397

Puspitasari, N. (2020). Analisis Proses Pembelajaran Dalam Jaringan Masa Pandemi Covid 19 Pada Guru Sd Negeri Dukuhwaru 01. MAGISTRA: Media Pengembangan Ilmu Pendidikan Dasar Dan Keislaman, 11(2), 170-186. Https://Doi.Org/10.31942/Mgs.V11i2.3943

Rifa'ie, M. (2020). Fleksibilitas Pembelajaran Daring Pada Masa Pandemi Covid-19 Flexibility Of Online Learning During Covid-19 Pandemic. Jurnal Pendidikan Dan Kebudayaan, 5, 197-205.

Salsabila, U. H., Sukriyanto, R., Purwanti, E., Purwaningsih, \& Satria, M. I. A. (2021). Peran Orang Tua Dalam Penggunaan Teknologi Pada Pembelajaran Online Tingkat SD Di Masa Pandemi Covid-19. Jurnal Inovasi Penelitian, 8(9), 1717-1718.

Sugiarti, \& Andalas, E. F. (2020). Membangun Optimisme Meretas Kehidupan Baru Dalam Dunia $\begin{array}{llllll}\text { Pendidikan } & \text { (Sugiarti } & \text { E. } & \text { F. } & \text { Andalas }\end{array}$ Https://Books.Google.Co.Id/Books/About/Membangun_Optimisme_Meretas_Kehidupan_Ba.Html?Id=3 bfwdwaaqbaj\&Redir_Esc $=Y$

Wahyono, P., Husamah, H., \& Budi, A. S. (2020). Guru Profesional Di Masa Pandemi COVID-19: Review Implementasi, Tantangan, Dan Solusi Pembelajaran Daring. Jurnal Pendidikan Profesi Guru, 1(1), 5165. Http://Ejournal.Umm.Ac.Id/Index.Php/Jppg/Article/View/12462 